Food, Dairy and Home Economic Research

http:/www.journals.zu.edu.eg/journalDisplay.aspx?Journalld=1\&queryType=Master

\title{
EFFECT OF ADDING GRAPE SEED POWDER AND IT'S EXTRACT ON THE COMPOSITION AND PROPERTIES OF PROCESSED CHEESE ANALOGUES
}

\author{
Nabeel B. Elgaml ${ }^{1}$, H.A. Ismail ${ }^{2 *}$ and A.S. Bakr ${ }^{3}$ \\ 1. Dairy Res. Dept., Anim. Prod. Res. Inst., Agric. Res. Cent., Minist. Agric., Cairo, Egypt \\ 2. Dairy Sci. Dept., Fac. Agric., Assiute Univ., New Valley Branch, Egypt \\ 3. Food Sci. and Technol. Dept., Fac. Agric., Tanta Univ., Egypt
}

Received: 26/04/2018 ; Accepted: 20/06/2018

\begin{abstract}
A new functional processed cheese fortified with grape seed powder (GSP) and its extract (GSE) was developed. The chemical composition, physical, microbiological properties, texture profile and sensory evaluation of prepared processed cheese were followed throughout storage period at $5^{\circ} \mathrm{C}$ up to 3 months. The moisture, ash, fat/dry matter (F/DM) and protein dry matter (P/DM) of supplemented processed cheeses were higher compared to control. While salt/moisture (S/M) content was lower. Addition of GSP and GSE increased the $\mathrm{pH}, \mathrm{SN}$ and antioxidant activity, but decreased the TVFA values and total bacteria count (TBC) compared with control, throughout storage. Significant differences were found between treatments and control processed cheese in texture profiles. Cheese fortified with up to $0.3 \%$ GSP and GSE exhibited better appearance, texture \&body and flavour. Further increase in the added ratio, significantly decreased the sensory scores compared with control.
\end{abstract}

Key words: Grape seeds powder, grape seeds extract, processed cheese analogues, cheese composition, physical characters, antioxidant activity, texture profile, sensory evaluation.

\section{INTRODUCTION}

Processed cheese has great popularity all over the world because of its favorable texture and taste, easy to handle, and its attractive image to all ages specially children (Mohamed and Shalaby, 2016). In response to increased manufacturing costs, imitation cheese products have been developed and are widely used, in pizza and fast food outlets, In addition, the manufacture of an imitation cheese allows the use of nutritional, textural and economic ingredients (Bachmann, 2001). Processed cheese made from mixing natural cheeses with salts and water under the influence of heat and agitation, whereas processed cheese analogues are made with partial or whole replacement of natural cheeses by milk proteins or other proteins (Gustaw and Mleko, 2007; Noronha et al., 2008). There are an increasing use of fruit processing wastes as functional food ingredients

\footnotetext{
* Corresponding author: Tel. : +201092550623

E-mail address: h_alshney@yahoo.com
}

because they are rich sources of dietary fiber and beneficial bioactive compounds, such as polyphenols, antioxidants and antimicrobial agents. Grape is one of the largest widely cultivated fruits all over the world (FAOSTAT, 2013). Grape by-products such as marcs, pomace, skins, seeds and stems have drawn increased attention in recent years for their potential health benefits not only as an antioxidant agents, but also as antibacterial, antiobesity, antithrombotic, and anti-carcinogenic agents (Park et al., 2008 ; Mildner-Szkudlarz and Bajerska, 2013). Grape seeds are waste products of the wine and grape juice industry which contain high amounts of fiber, valuable lipid, proteins, carbohydrates, sugars, minerals, antioxidants and polyphenols (Kim et al., 2006; Arora et al., 2010). The moisture, fat, protein, fiber, ash and nitrogen free extract of grape seed powders were reported to be $6.93,7.39,18.89$, 48.90, 0.33 and $17.56 \%$, respectively (Abdrabba 
and Hussein, 2015). It has been reported that grape seed oils contain large amounts of unsaturated fatty acids such as linoleic and oleic, and sitosterol, as the main sterol constituent (Ohnishi et al., 1990). Grape seed extract has been reported to possess a broad spectrum of pharmacological and therapeutic effects including anti-inflammatory, anti-arthritic, antiallergic effects, prevent heart diseases, reduced apoptotic cell death and skin aging activity (Maffei et al., 1996). The polyphenols of grape seeds exhibit a strong antioxidant activity. The antioxidant potential of grape seeds proanthocyanidins was reported to be 20 times higher than vitamin $\mathrm{E}$ and 50 times more than vitamin C (Bagchi et al., 1997). Grape seed extract has been used as natural food additives and antioxidant in Japan (Nakamura et al., 2003) and has been marketed in France for decades as treatment for venous and vascular capillary disorders (Arora et al., 2010) and for treatment of liver and gall bladder dysfunctions in Europe in many centuries (Wichtl, 2004). Several studies has been used grape seed extract in yoghurt, frankfurters and bread to increase the concentration of beneficial compounds in the final product (Sant'Anna et al., 2014).

The objectives of the present study were to assessment the potential use of grape seed powders and its extract in the manufacture of processed cheese analogues.

\section{MATERIALS AND METHODS}

\section{Materials}

Red grape (Vitis vinifera L.) was purchased from local market. The ingredients of cheese formula were vegetables fat (shorting) obtained from Arma Co., Malysia. Modified starch produced by Fude and Serrahn, Germany, low heat skim milk powder (96\% dry matter, $32.5 \%$ protein and $1.5 \%$ fat) imported from USA (Dairy America California), vegetable protein (protein $8 \%$ ) by Fonterra Co., Newzeland, whey powder $(95 \%$ dry matter, $6.5 \%$ protein and $2 \%$ fat) obtained from ARAB Co. for import and export, Cairo, Egypt. Emulsify salt (B4), was supplied by Dairy Products and Food Additives (EGY Dairy), Egypt. Salt $(\mathrm{NaCl})$, potassium sorbate, citric acid and nisin were purchased from Misr Food Additives (Mifad), Egypt.
These ingredients were supplied by Green field factory, Desok, Kafer- Elshekh, Egypt. The 2,2diphenyl 1-picryhydrazl (DPPH) was purchased from Sigma Chemical Co. USA.

\section{Preparation of grape seed powder and its extract}

Grape seeds were separated from the grapes, washed, air dried in shade at $25-30^{\circ} \mathrm{C}$, ground using a house blender and then sieved to obtain fine powder (GSP). Grape seed extract (GSE) was prepared by macerating of GSP $50 \mathrm{~g}$ in 250 $\mathrm{ml}$ distilled water at $5^{\circ} \mathrm{C}$ for $24 \mathrm{hr}$., and filtered through cheese cloth.

\section{Preparation of processed cheese analogues fortified with GSP and GSE}

GSP and GSE were added in the formulation of processed cheese analogues (Table 1) at the ratio of 0.0 (control), 0.1 and $0.3 \%$ as called GSP 1, GSP 2 and GSE1, GSE2, respectively. The ingredients for each formula were placed in the cooking vat mixed for $1 \mathrm{~min}$ at low speed, $\mathrm{pH}$ was adjusted to ca. 5.8 with citric acid, vacuum was applied and, the content was heated up to $70^{\circ} \mathrm{C}$ by direct steam injection. Vacuum was switched off and heating was reached up to $95^{\circ} \mathrm{C}$ and the ingredients were mixed at high speed for $2 \mathrm{~min}$. The hot cheese melt was transferred into a plastic lined cardboard box with dimensions $6 \times 10 \times 6 \mathrm{~cm}$ and placed in the refrigerator. All samples from each treatment were stored at $5^{\circ} \mathrm{C}$ for 3 months. The chemical, physical, microbiological, texture profile and sensory evaluation were carried out on fresh processed cheese and after 1,2 and 3 months.

\section{Methods of analysis}

Cheese samples were analyzed for moisture, fat, protein, salt, ash and water-soluble nitrogen (WSN) according to the methods described in AOAC (2000). The $\mathrm{pH}$ values were measured in cheese samples using $\mathrm{pH}$ meter (SGH, CG-811England). Total volatile fatty acids were determined as given by Kosikowski (1978). Analysis was performed in triplicate and results reported as mean.

\section{Determination of antioxidant activity}

The antioxidant activity was determined using 2, 2-Diphenyl 1-picrylhydrazyl (DPPH) method according to Lee $\boldsymbol{e t}$ al. (2003). Radical 
Table 1. Chemical composition of the ingredients used in manufacture of processed cheese analogues $(\mathrm{kg} / \mathbf{1 0 0} \mathrm{kg})$

\begin{tabular}{lc}
\hline Component & Quantity \\
\hline Vegetables fat (shorting), & 19.80 \\
Modified starch & 13.50 \\
Skimmed milk powder & 3.90 \\
Salt (NaCl) & 1.52 \\
Vegetables protein & 1.30 \\
Emulsify salt (B4), & 1.28 \\
Whey powder & 0.72 \\
Potassium sorbate & 0.19 \\
Citric acid & 0.08 \\
Nisin & 0.03 \\
Water & 57.68 \\
Total & $\mathbf{1 0 0}$ \\
\hline
\end{tabular}

scavenging activity was expressed as inhibition percentage and was calculated using the following formula:

DPPH radical scavenging activity $(\%)=(1$ - sample absorbance/control absorbance) $\times 100$.

\section{Texture profile analysis}

The textural profile analysis test (TPA) including hardness, springiness, cohesiveness adhesiveness, gumminess and chewiness of processed cheese was done on the prepared cheese analogues by LFRA-Texture Analyzer (1000) using computer interface software (CNS Farnell, Bore Harwood, Hertfordshire, England WD6 1WG) according to Bourne (1982). The samples were analyzed when fresh and after 1,2 and 3 months.

\section{Microbiological examination}

The samples were examined for total viable bacterial .Total viable bacteria were enumerated by pour plate method using standard plate count agar (Houghtby et al., 1992) and the plates were incubated at $37^{\circ} \mathrm{C}$ for $48 \mathrm{hr}$.

\section{Sensory evaluation}

Processed cheeses analogues treatments were sensory evaluated by 10 staff members at the
Animal Production Res. Institute, Agric. Res. Center, Ministry of Agric., Egypt. The score card was designed as suggested by Meyer (1973) for: appearance (out of 20 points), body and texture (out of 40 points), flavour (out of 40 points), and total acceptability (sum for scores for appearance, body \&texture and flavour).

\section{Statistical Analysis}

SPSS (Version 20.0) software was used for statistical analysis using analysis ANOVA, significant means were compared using Duncan's test at the level of $\mathrm{P}<0.05$.

\section{RESULTS AND DISCUSSION}

\section{Compositional Analysis of Processed Cheese Analogues}

The changes in gross chemical composition of the prepared processed cheese analogoues supplemented with GSP and GSE are shown in Table 2 . The GSE fortified cheese had significantly higher moisture content compared with GSP or control treatments. This may be due to the nonphenolic material in grape seeds which possibly bind water and contribute to higher cheese moisture content (Felix da Silva et al., 2015). 
Table 2. Chemical composition of processed cheese analogoues supplement with grape seeds powder and its extracts during storage at $5^{\circ} \mathrm{C}$ up to three months

\begin{tabular}{|c|c|c|c|c|c|c|}
\hline \multirow[t]{2}{*}{ Item (\%) } & \multirow{2}{*}{$\begin{array}{l}\text { Storage } \\
\text { period } \\
\text { (month) }\end{array}$} & \multicolumn{5}{|c|}{ Treatment } \\
\hline & & Control & GSP1 & GSP2 & GSE1 & GSE2 \\
\hline \multirow{5}{*}{ Moisture } & Fresh & $54.96 \pm 0.94 \mathrm{~d}$ & $55.49 \pm 002 \mathrm{c}$. & $56.54 \pm 0.05 \mathrm{c}$ & $56.89 \pm 0.09 \mathrm{~b}$ & $57.96 \pm 0.06 \mathrm{a}$ \\
\hline & 1 & $54.51 \pm 0.16 \mathrm{~d}$ & $55.45 \pm 0.02 \mathrm{c}$ & $55.98 \pm 0.04 \mathrm{c}$ & $56.71 \pm 0.04 \mathrm{~b}$ & $57.48 \pm 0.32 \mathrm{a}$ \\
\hline & 2 & $54.42 \pm 0.14 \mathrm{e}$ & $55.41 \pm 0.02 \mathrm{~d}$ & $55.87 \pm 0.03 \mathrm{c}$ & $56.65 \pm 0.04 \mathrm{~b}$ & $57.55 \pm 0.03 \mathrm{a}$ \\
\hline & 3 & $54.32 \pm 0.12 \mathrm{e}$ & $55.38 \pm 0.03 \mathrm{~d}$ & $55.74 \pm 0.03 \mathrm{c}$ & $56.55 \pm 0.04 \mathrm{~b}$ & $57.46 \pm 0.03 \mathrm{a}$ \\
\hline & Mean \pm SD & $54.55 \pm 0.08 \mathrm{e}$ & $55.42 \pm 0.02 \mathrm{~d}$ & $56.03 \pm 0.02 \mathrm{c}$ & $56.70 \pm 0.02 \mathrm{~b}$ & $57.61 \pm 0.11 \mathrm{a}$ \\
\hline \multirow{4}{*}{ Fat/DM } & Fresh & $51.29 \pm 0.0 \mathrm{~cd}$ & $51.53 \pm 0.04 b c$ & $51.91 \pm 0.63 \mathrm{~d}$ & $51.61 \pm 0.07 \mathrm{~b}$ & $52.59 \pm 0.03 \mathrm{a}$ \\
\hline & 1 & $50.45 \pm 0.10 \mathrm{~d}$ & $51.13 \pm 0.03 \mathrm{~b}$ & $51.16 \pm 0.04 \mathrm{c}$ & $51.22 \pm 0.04 \mathrm{~b}$ & $51.86 \pm 0.04 \mathrm{a}$ \\
\hline & 2 & $50.19 \pm 0.16 \mathrm{c}$ & $50.84 \pm 0.07 \mathrm{~b}$ & $50.94 \pm 0.06 \mathrm{~b}$ & $50.93 \pm 0.4 \mathrm{bc}$ & $51.76 \pm 0.06 \mathrm{a}$ \\
\hline & 3 & $49.98 \pm 0.17 \mathrm{~d}$ & $50.49 \pm 0.09 \mathrm{~b}$ & $50.68 \pm 0.07 \mathrm{c}$ & $50.61 \pm 0.0 b c$ & $51.40 \pm 0.08 \mathrm{a}$ \\
\hline \multirow{6}{*}{$\begin{array}{c}\text { Protein/ } \\
\text { DM }\end{array}$} & Mean \pm SD & $50.48 \pm 0.11 \mathrm{~d}$ & $51.01 \pm 0.04 \mathrm{~b}$ & $50.93 \pm 0.14 \mathrm{c}$ & $51.09 \pm 0.11 \mathrm{~b}$ & $51.90 \pm 0.03 \mathrm{a}$ \\
\hline & Fresh & $29.09 \pm 0.17 \mathrm{a}$ & $29.22 \pm 0.06 \mathrm{a}$ & $29.25 \pm 0.23 \mathrm{a}$ & $30.22 \pm 0.10 \mathrm{a}$ & $31.04 \pm 0.03 \mathrm{a}$ \\
\hline & 1 & $28.69 \pm 0.12 \mathrm{~d}$ & $28.96 \pm 0.07 \mathrm{c}$ & $29.00 \pm 0.03 \mathrm{c}$ & $29.98 \pm 0.08 \mathrm{~b}$ & $30.73 \pm 0.06 \mathrm{a}$ \\
\hline & 2 & $28.21 \pm 0.15 \mathrm{~d}$ & $28.78 \pm 0.08 \mathrm{c}$ & $28.91 \pm 0.08 \mathrm{c}$ & $29.66 \pm 0.05 b$ & $30.45 \pm 0.08 \mathrm{a}$ \\
\hline & 3 & $28.06 \pm 0.04 \mathrm{e}$ & $28.99 \pm 0.05 \mathrm{c}$ & $29.05 \pm 0.06 \mathrm{~d}$ & $29.35 \pm 0.08 \mathrm{~b}$ & $29.93 \pm 1.28 \mathrm{a}$ \\
\hline & Mean \pm SD & $28.52 \pm 0.11 \mathrm{c}$ & $28.94 \pm 0.04 \mathrm{c}$ & $28.99 \pm 0.05 \mathrm{c}$ & $29.81 \pm 0.03 \mathrm{~b}$ & $30.81 \pm 0.32 \mathrm{a}$ \\
\hline \multirow{4}{*}{ Salt/M } & Fresh & $3.51 \pm 0.01 \mathrm{~b}$ & $3.38 \pm 0.02 \mathrm{~b}$ & $3.27 \pm 0.04 \mathrm{~b}$ & $3.20 \pm 0.02 \mathrm{~b}$ & $3.11 \pm 0.02 \mathrm{a}$ \\
\hline & $\mathbf{1}$ & $3.49 \pm 0.01 \mathrm{~b}$ & $3.28 \pm 0.03 \mathrm{~d}$ & $3.20 \pm 0.02 \mathrm{~cd}$ & $3.16 \pm 0.05 \mathrm{c}$ & $3.06 \pm 0.06 \mathrm{a}$ \\
\hline & 2 & $3.45 \pm 0.01 \mathrm{a}$ & $3.25 \pm 0.03 \mathrm{a}$ & $3.15 \pm 0.04 \mathrm{a}$ & $3.14 \pm 0.23 \mathrm{a}$ & $3.01 \pm 0.05 \mathrm{a}$ \\
\hline & 3 & $3.42 \pm 0.04 \mathrm{a}$ & $3.23 \pm 0.06 \mathrm{~b}$ & $3.07 \pm 0.03 \mathrm{~b}$ & $3.11 \pm 0.09 \mathrm{a}$ & $2.87 \pm 0.06 \mathrm{~b}$ \\
\hline \multirow{6}{*}{ Ash } & Mean \pm SD & $3.47 \pm 0.00 \mathrm{a}$ & $3.28 \pm 0.02 \mathrm{~b}$ & $3.17 \pm 0.03 \mathrm{~b}$ & $3.15 \pm 0.03 \mathrm{a}$ & $3.01 \pm 0.04 \mathrm{a}$ \\
\hline & Fresh & $3.32 \pm 0.02 \mathrm{e}$ & $3.42 \pm 0.01 \mathrm{~d}$ & $3.73 \pm 0.02 \mathrm{c}$ & $3.85 \pm 0.01 \mathrm{~b}$ & $3.96 \pm 0.04 \mathrm{a}$ \\
\hline & 1 & $3.28 \pm 0.01 \mathrm{e}$ & $3.35 \pm 0.02 \mathrm{~d}$ & $3.65 \pm 0.03 \mathrm{c}$ & $3.80 \pm 0.02 \mathrm{~b}$ & $3.86 \pm 0.03 \mathrm{a}$ \\
\hline & 2 & $3.24 \pm 0.02 \mathrm{~d}$ & $3.31 \pm 0.02 \mathrm{c}$ & $3.59 \pm 0.02 \mathrm{~b}$ & $3.74 \pm 0.02 \mathrm{a}$ & $3.75 \pm 0.03 \mathrm{a}$ \\
\hline & 3 & $3.14 \pm 0.02 \mathrm{~d}$ & $3.27 \pm 0.01 \mathrm{c}$ & $3.53 \pm 0.02 \mathrm{~b}$ & $3.65 \pm 0.04 \mathrm{a}$ & $3.65 \pm 0.03 \mathrm{a}$ \\
\hline & Mean \pm SD & $3.25 \pm 0.00 \mathrm{e}$ & $3.34 \pm 0.00 \mathrm{~d}$ & $3.63 \pm 0.01 \mathrm{c}$ & $3.76 \pm 0.02 \mathrm{~b}$ & $3.81 \pm 0.03 \mathrm{a}$ \\
\hline \multicolumn{7}{|c|}{$\begin{array}{l}\text { Values are expressed as the mean standard deviation of three determinations. } \\
\text { a b c d e } \text { Letters indicate significant differences between processed cheese analogoues treatments. }\end{array}$} \\
\hline$P$ & & & er. & &. & $\begin{array}{l}\text { pe seeds powder. } \\
\text { pe seeds extract. }\end{array}$ \\
\hline
\end{tabular}


The F/ DM and P/DM (\%) were lower in control than cheese treatments. The F/DM and P/DM (\%) in GSE cheeses was more than GSP cheeses and increased with increasing the level of addition. Throughout storage, F/DM and P/DM (\%) decreased in all cheeses. Significant differences $(\mathrm{P}<0.05)$ were found between GSE and control cheeses in fresh and through storage period. The S/M (\%) was higher in control cheese compared with GSP and GSE processed cheeses. Cheeses fortified with GSP had higher S/M (\%) than that GSE cheeses, without significant differences. The salt content of cheese in all treatments and control decreased slightly through storage period. On the other hand, experimental processed cheese had higher ash content compared to the control. The ash contents of the GSE cheese augmentation than that in GSP cheese. The ash contents of the treated cheeses were increased with increasing levels of GSP and GSE. Slight decrease in ash content was observed in all cheeses throughout the storage period.

\section{Physical Characteristics of Processed Cheese}

Table 3 shows some physical characteristics of processed cheese. The $\mathrm{pH}$ value of GSP and GSE cheese was slightly higher than that of control processed cheese. This trend is in accordance with that reported by Mohamed $\boldsymbol{e t}$ al. (2014) for yoghurt. The $\mathrm{pH}$ values were decreased gradually in all treatments throughout the storage, which can be attributed to the decomposition in the emulsifying salts and/or their interaction with protein (Chamber and Daurelles, 2000). The SN (\%) was found to be significantly lower in control cheese compared to that containing GSP and GSE. Noticeable increase in SN (\%) occurred in GSE cheese compared with GSP cheese. The high SN (\%) of treated cheeses may be attributed to the soluble protein contend of GSP and GSE. During storage, the value of $\mathrm{SN}$ increased in all cheeses, could be due to the hydrolysis of polyphosphate in emulsifying salts which caused more solubilization of proteins (Awad and Salama, 2010). The total volatile fatty acids (TVFA) were more abundant in control as compared to those of supplemented processed cheeses. However, the GSP cheese had higher TVFA than GSE cheese, whereas increasing the concentration of GSP or GSE decreased the TVFA values in cheese. On the contrary, TVFA values increased in all treatments and control cheese through storage period.

\section{Antioxidant Activity}

The antioxidant activity of phenolic compounds is mainly attributed to their free radical scavenging and metal chelating properties. A difference in the antioxidant scavenging activity was noticed between GSP, GSE and control processed cheeses when fresh and throughout storage period (Table 3). The values of antioxidant scavenging activity were higher in GSP or GSE cheeses as compared with control cheese. On the other hand, GSE cheeses had the greatest value of antioxidant scavenging activity. These differences were increased with the increase of added GSP and GSE ratios. Similar results for GSE were obtained by Jayaprakasha et al. (2003). The antioxidant values of all processed cheeses decreased by advancing of the storage period.

\section{Microbiological Examination}

The processed cheese analogoues was compared for total bacterial (TBC) count (Table 4). The results indicated that higher TBC were detected in control cheese than cheese supplemented with GSP or GSE. The reduction of the bacterial populations might be occurred due to the high phenolic compound content of grape seeds that are known as antimicrobial agents, may alter the cell morphology by influencing the osmotic pressure of the cell, thus disrupting the cytoplasmic membrane and causing leakage of cell constituents (Shin et al., 2012). Furthermore TBC of GSP cheeses were slightly higher than GSE cheeses. Chedea et al. (2011) reported that GSE contains gallic acid which conceder the most active compound for inhibition of bacteria. Therefore, current results indicated that using GSP and GSE may be exploiting antimicrobial agents that prevent the spoilage of stored dairy products by bacteria. The storage period leads to the decrease in bacterial counts.

\section{Texture Profile Analysis}

In the current study, there is factor efficient to rheological parameters of cheese, it is the 
Table 3. Physicochemical composition of processed cheese analogoues supplement with grape seeds powder and its extracts during storage at $5^{\circ} \mathrm{C}$ up to three months

\begin{tabular}{|c|c|c|c|c|c|c|}
\hline \multirow[t]{2}{*}{ Item } & \multirow{2}{*}{$\begin{array}{l}\text { Storage } \\
\text { period } \\
\text { (month) }\end{array}$} & \multicolumn{5}{|c|}{ Treatment } \\
\hline & & Control & GSP1 & GSP2 & GSE1 & GSE2 \\
\hline \multirow{4}{*}{ pH value } & Fresh & $5.88 \pm 0.01 \mathrm{c}$ & $5.95 \pm 0.01 \mathrm{a}$ & $5.92 \pm 0.01 \mathrm{~b}$ & $5.91 \pm 0.02 \mathrm{~b}$ & $5.93 \pm 0.02 \mathrm{ab}$ \\
\hline & 1 & $5.66 \pm 0.04 c$ & $5.86 \pm 0.03 a$ & $5.86 \pm 0.03 \mathrm{a}$ & $5.76 \pm 0.03 b$ & $5.84 \pm 0.02 \mathrm{a}$ \\
\hline & 2 & $5.63 \pm 0.02 b$ & $5.77 \pm 0.02 \mathrm{a}$ & $5.77 \pm 0.03 \mathrm{a}$ & $5.66 \pm 0.02 b$ & $5.76 \pm 0.03 a$ \\
\hline & 3 & $5.58 \pm 0.01 b$ & $5.67 \pm 0.03 a$ & $5.65 \pm 0.02 \mathrm{a}$ & $5.59 \pm 0.02 b$ & $5.66 \pm 0.03 a$ \\
\hline \multirow{6}{*}{$\mathrm{SN}(\%)$} & Mean \pm SD & $5.69 \pm 0.01 \mathrm{c}$ & $5.81 \pm 0.01 \mathrm{a}$ & $5.80 \pm 0.02 \mathrm{a}$ & $5.73 \pm 0.02 b$ & $5.80 \pm 0.01 \mathrm{a}$ \\
\hline & Fresh & $1.32 \pm 0.01 \mathrm{c}$ & $1.46 \pm 0.01 \mathrm{~b}$ & $1.44 \pm 0.02 b$ & $1.55 \pm 0.04 \mathrm{a}$ & $1.46 \pm 0.03 b$ \\
\hline & 1 & $1.45 \pm 0.02 \mathrm{~d}$ & $1.54 \pm 0.03 \mathrm{cb}$ & $1.49 \pm 0.02 \mathrm{dc}$ & $1.64 \pm 0.03 \mathrm{a}$ & $1.56 \pm 0.04 b$ \\
\hline & 2 & $1.57 \pm 0.02 b$ & $1.65 \pm 0.02 \mathrm{a}$ & $1.57 \pm 0.02 b$ & $1.67 \pm 0.03 \mathrm{a}$ & $1.66 \pm 0.04 \mathrm{a}$ \\
\hline & 3 & $1.65 \pm 0.05 \mathrm{a}$ & $1.73 \pm 0.12 \mathrm{a}$ & $1.65 \pm 0.03 a$ & $1.74 \pm 0.03 \mathrm{a}$ & $1.69 \pm 0.03 \mathrm{a}$ \\
\hline & Mean \pm SD & $1.50 \pm 0.02 \mathrm{c}$ & $1.59 \pm 0.04 b$ & $1.54 \pm 0.01 \mathrm{c}$ & $1.65 \pm 0.02 \mathrm{a}$ & $1.59 \pm 0.03 b$ \\
\hline \multirow{5}{*}{$\begin{array}{c}\text { TVFA } \\
(\mathrm{ml} \mathrm{0.1N} \\
\mathrm{NaOH} / \\
100 \mathrm{~g})\end{array}$} & Fresh & $29.00 \pm 1.00 \mathrm{a}$ & $26.20 \pm 1.05 \mathrm{a}$ & $25.13 \pm 0.95 a$ & $25.74 \pm 6.54 \mathrm{a}$ & $25.05 \pm 0.21 \mathrm{a}$ \\
\hline & 1 & $33.20 \pm 0.10 \mathrm{a}$ & $28.47 \pm 0.90 \mathrm{~b}$ & $26.33 \pm 1.05 \mathrm{dc}$ & $27.27 \pm 1.60 \mathrm{cb}$ & $25.37 \pm 0.90 \mathrm{~d}$ \\
\hline & 2 & $38.40 \pm 0.10 \mathrm{a}$ & $32.37 \pm 1.01 \mathrm{~b}$ & $29.23 \pm 1.15 c$ & $31.60 \pm 1.54 b$ & $27.40 \pm 0.70 \mathrm{c}$ \\
\hline & 3 & $40.33 \pm 0.15 \mathrm{a}$ & $35.44 \pm 1.01 \mathrm{~b}$ & $32.21 \pm 1.15 \mathrm{c}$ & $35.37 \pm 0.97 b$ & $31.22 \pm 0.95 c$ \\
\hline & Mean \pm SD & $35.23 \pm 0.24 \mathrm{a}$ & $30.62 \pm 0.99 b$ & $28.23 \pm 0.94 c$ & $30.00 \pm 0.97 b$ & $27.26 \pm 0.66 c$ \\
\hline \multirow{5}{*}{$\begin{array}{l}\text { Anti- } \\
\text { oxidants } \\
\text { activity } \\
(\%)\end{array}$} & Fresh & $6.74 \pm 0.04 \mathrm{e}$ & $12.17 \pm 0.04 d$ & $17.61 \pm 0.04 c$ & $23.08 \pm 0.03 b$ & $28.09 \pm 0.04 \mathrm{a}$ \\
\hline & 1 & $5.82 \pm 0.04 \mathrm{e}$ & $10.15 \pm 0.04 d$ & $12.55 \pm 0.04 c$ & $16.24 \pm 0.04 b$ & $19.75 \pm 0.03 \mathrm{a}$ \\
\hline & 2 & $2.14 \pm 0.04 \mathrm{e}$ & $8.15 \pm 0.04 d$ & $8.52 \pm 0.03 \mathrm{c}$ & $10.16 \pm 0.04 b$ & $10.94 \pm 0.03 \mathrm{a}$ \\
\hline & 3 & $0.65 \pm 0.04 \mathrm{e}$ & $7.19 \pm 0.05 \mathrm{c}$ & $7.36 \pm 0.04 b$ & $7.75 \pm 0.02 \mathrm{a}$ & $7.90 \pm 0.03 \mathrm{~d}$ \\
\hline & Mean \pm SD & $3.84 \pm 0.03 \mathrm{e}$ & $9.41 \pm 0.01 \mathrm{~d}$ & $11.51 \pm 0.01 \mathrm{c}$ & $14.31 \pm 0.03 b$ & $12.86 \pm 0.01 \mathrm{a}$ \\
\hline
\end{tabular}

Table 4. Total bacterial count $\left(\log _{10}-\mathrm{CFU}\right)$ of processed cheese analogoues supplement with grape seeds powder and its extracts during storage at $5^{\circ} \mathrm{C}$ up to three months

\begin{tabular}{cccccc}
\hline $\begin{array}{c}\text { Storage } \\
\text { period } \\
\text { (month) }\end{array}$ & \multicolumn{6}{c}{ Control } & GSP1 & GSP2 & GSE1 & GSE2 \\
\cline { 2 - 6 } & & & & & \\
\hline Fresh & $7.71 \pm 0.01 \mathrm{a}$ & $7.63 \pm 0.01 \mathrm{~b}$ & $7.49 \pm 0.01 \mathrm{~d}$ & $7.62 \pm 0.02 \mathrm{~b}$ & $7.56 \pm 0.01 \mathrm{c}$ \\
$\mathbf{1}$ & $6.65 \pm 0.01 \mathrm{~b}$ & $6.62 \pm 0.01 \mathrm{ab}$ & $6.51 \pm 0.08 \mathrm{c}$ & $6.57 \pm 0.01 \mathrm{bc}$ & $6.52 \pm 0.01 \mathrm{bc}$ \\
$\mathbf{2}$ & $6.60 \pm 0.02 \mathrm{a}$ & $6.57 \pm 0.01 \mathrm{~b}$ & $6.44 \pm 0.01 \mathrm{~d}$ & $6.54 \pm 0.01 \mathrm{~b}$ & $6.49 \pm 0.02 \mathrm{c}$ \\
$\mathbf{3}$ & $5.56 \pm 0.02 \mathrm{~d}$ & $5.43 \pm 0.02 \mathrm{~b}$ & $5.41 \pm 0.02 \mathrm{~b}$ & $5.42 \pm 0.02 \mathrm{~b}$ & $5.40 \pm 0.02 \mathrm{~b}$ \\
Mean \pm SD & $6.63 \pm 0.79 \mathrm{a}$ & $6.56 \pm 0.81 \mathrm{~b}$ & $6.46 \pm 0.77 \mathrm{~d}$ & $6.54 \pm 0.80 \mathrm{~b}$ & $6.49 \pm 0.79 \mathrm{c}$ \\
\hline
\end{tabular}

Values are expressed as the mean standard deviation of three determinations.

a b c d e Letters indicate significant differences between processed cheese analogoues treatments.

Control: processed cheese without grape seeds.

GSP1: processed cheese containing $0.1 \%$ grape seeds powder.

GSP2: processed cheese containing $0.3 \%$ grape seeds powder. GSE1: processed cheese containing $0.1 \%$ grape seeds extract.

GSE2: processed cheese containing $0.3 \%$ grape seeds extract. 
modified starch. The modified starch has caused a more rigid structure with molecules strongly correlated. The partially molten fat fills the spaces in the matrix of casein and starch which increases the elasticity of cheese (Benaouadj $\boldsymbol{e t}$ al., 2017). The modified starch is gelatinized and thus it forms a gel (Chemache, 2011). Texture profile analysis of processed cheese analogues are given in Fig.1. Hardness values were higher in control processed cheese than that in GSP followed by GSE cheeses. However, hardness decreased with increasing percentage of the ratio added. The decrease in moisture content may be responsible for the increase in hardness due to the greater hydration and consequent weakening of the casein network (Pereira et al., 2001). The decrease in $\mathrm{pH}$ value may be another factor in the observed increase in hardness. The results also showed that in the supplemented processed cheese, cohesiveness, springiness and chewiness values increased comparing to the control. In addition showed higher values in GSE than GSP cheeses and with increasing the levels of fortification. The results showed that cohesiveness, springiness and chewiness values of all cheeses were significantly decreased during the storage. Rising of S/M may increase the possibility for replacement of $\mathrm{Ca}^{2+}$ with $\mathrm{Na}^{+}$, thereby decreasing the firmness of cheese. Chewiness was secondary textural parameters of cheese, know it is the number of chews that are required before the sample is ready for swallowing (Gwartney et al., 2004). The suitable chewiness provides a rich mouth feel and enhances the joy of tasting cheese. The higher moisture and fat contents lead to lower the firmness of cheese. On contrary, the higher protein and dry matter contents, leads to higher firmness of cheese (Zheng et al., 2016). Adhesiveness values were significantly higher $(\mathrm{P}<0.05)$ in control cheese than supplemented processed cheese. As well, adhesiveness values in GSP cheeses was higher than that in GSE cheeses and increased with increasing the added ratios. Adhesiveness values in all cheese increased gradually during the storage period. It could be noticed that gumminess values were similar in supplemented cheeses and control with decreased the advance of storage period. Bourne (2002) reported that gumminess is directly proportional to firmness, and therefore, gumminess decreases with reduced firmness.

\section{Sensory Evaluation}

Sensory evaluation of processed cheese analogues supplemented with GSP and GSE at different levels is shown in Table 5. Significant differences were found in the appearance, body and texture and flavour between control, GSP and GSE cheeses. Increasing the level of grape seeds powder in the cheese formulation led to better flavour scores. The profound positive impact of utilizing grape seeds on flavour and taste scores of product, possibly to the phenolic compounds (Mohamed et al., 2014). Cheeses fortified with $0.3 \%$ GSP or GSE had better appearance, body and texture and flavour than control cheese throughout storage period. Considering that at the end of storage, decreased colour scores of the supplemented cheese, reduction in acceptability was expected, but was not the case, panelists preferred GSP and GSE cheeses. The highest overall acceptability score was associated with cheese containing GSP or GSE at level of $0.3 \%$.

\section{Conclusion}

Fortifying processed cheese with grape seeds is of great interest to improve the functionality and create functional type of cheese with health benefits. Addition of grape seeds to cheese would complement its healthy characteristics; improve rheological properties, and development sensory features. Fortifying processed cheese with $0.3 \%$ of grape seeds or its extract produced acceptable product. It must be noted that the utilization of by-products for formulation of functional food, and so can transfer the status of analogues products from an 'inferior' product to a functional food with health benefits.

\section{Acknowledgements}

The authors sincerely thank Green-fields factory for providing raw materials and harnessing its capabilities in the manufacturing process. 

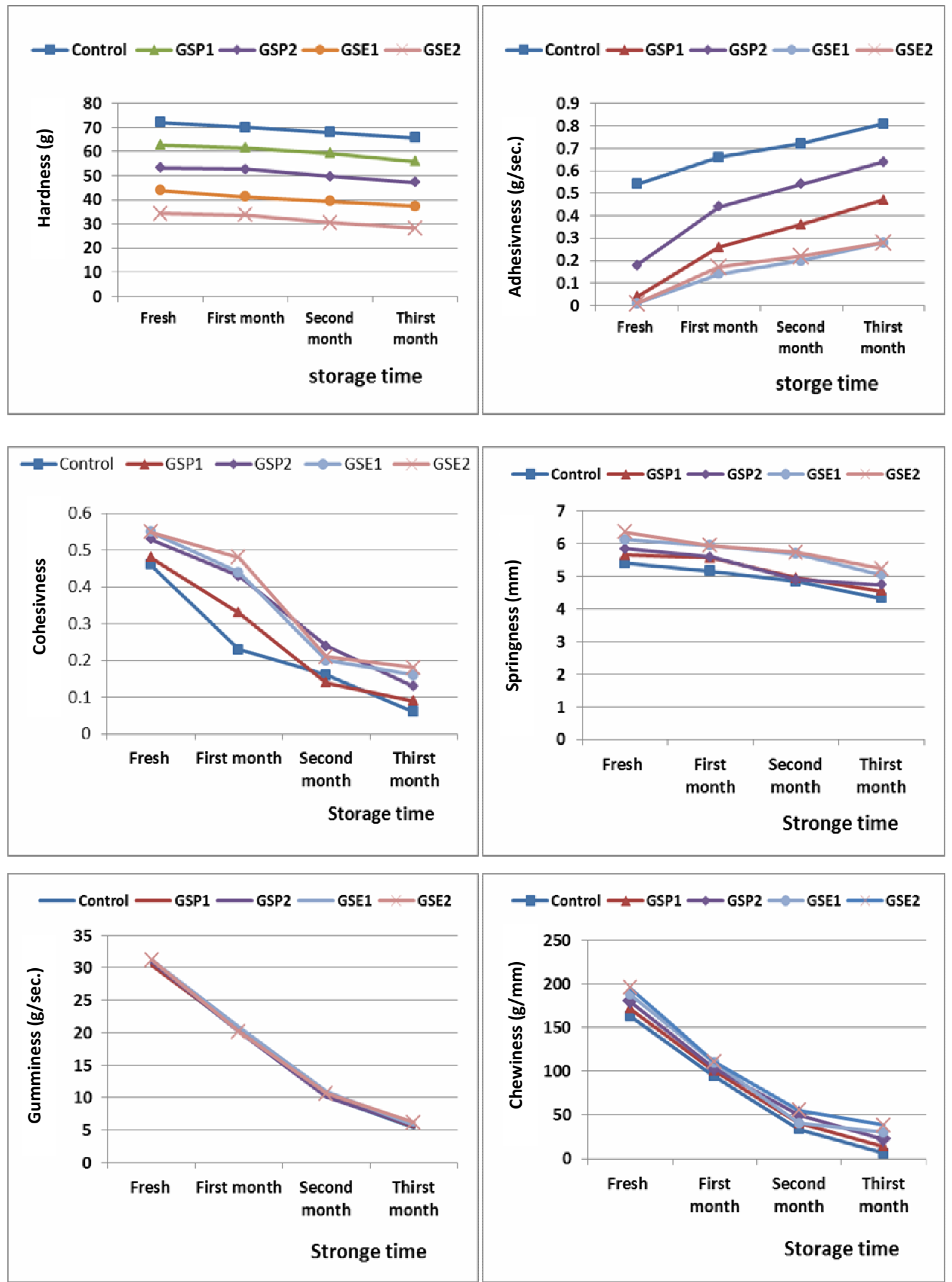

Fig. 1. Texture profile analysis of processed cheese analogoues supplement with grape seeds powder and its extracts during storage at $5^{\circ} \mathrm{C}$ up to three months 
Table 5. Sensory evaluation of processed cheese analogoues supplement with grape seeds powder and its extracts during storage at $5^{\circ} \mathrm{C}$ up to three months

\begin{tabular}{|c|c|c|c|c|c|}
\hline \multirow{2}{*}{$\begin{array}{c}\text { Storage } \\
\text { period } \\
\text { (month) }\end{array}$} & \multirow[t]{2}{*}{ Control } & \multicolumn{2}{|c|}{ Seeds powder } & \multicolumn{2}{|c|}{ Seeds extract } \\
\hline & & GSP1 & GSP2 & GSE1 & GSE2 \\
\hline & \multicolumn{5}{|c|}{ Appearance (20) } \\
\hline Fresh & $17.0 \pm 0.00 \mathrm{~b}$ & $18.0 \pm 0.00 \mathrm{ab}$ & $18.3 \pm 0.58 \mathrm{a}$ & $17.7 \pm 0.58 \mathrm{ab}$ & $18.7 \pm 1.15 \mathrm{a}$ \\
\hline 1 & $17.7 \pm 0.58 \mathrm{~b}$ & $18.0 \pm 1.00 \mathrm{~b}$ & 18. $7 \pm 1.15 \mathrm{ab}$ & $18.0 \pm 0.00 \mathrm{~b}$ & $19.7 \pm 0.58 \mathrm{a}$ \\
\hline 2 & $18.0 \pm 1.00 \mathrm{c}$ & $18.3 \pm 1.15 \mathrm{bc}$ & 19. $7 \pm 0.58 \mathrm{ab}$ & 19. $7 \pm 0.58 \mathrm{ab}$ & $20.0 \pm 0.00 \mathrm{a}$ \\
\hline 3 & $19.0 \pm 1.00 \mathrm{ab}$ & 19. $7 \pm 0.58 \mathrm{a}$ & $20.0 \pm 0.00 \mathrm{a}$ & $20.0 \pm 0.00 \mathrm{a}$ & $19.7 \pm 0.58 \mathrm{a}$ \\
\hline \multirow[t]{2}{*}{ Mean \pm SD } & $17.9 \pm 0.52 \mathrm{de}$ & $18.4 \pm 0.33 \mathrm{~cd}$ & $19.1 \pm 0.19 \mathrm{ab}$ & 18. $7 \pm 0.14 \mathrm{bc}$ & $19.4 \pm 0.25 \mathrm{a}$ \\
\hline & \multicolumn{5}{|c|}{ Body and texture (40) } \\
\hline Fresh & $37.0 \pm 1.00 \mathrm{a}$ & $37.0 \pm 2.00 \mathrm{a}$ & $37.00 \pm 1.00 \mathrm{a}$ & $37.0 \pm 1.0 \mathrm{a}$ & $38.0 \pm 1.00 \mathrm{a}$ \\
\hline 1 & $37.0 \pm 2.00 \mathrm{ab}$ & $37.3 \pm 1.53 \mathrm{ab}$ & $37.7 \pm 0.58 \mathrm{a}$ & $37.0 \pm 1.00 \mathrm{ab}$ & $38.3 \pm 0.58 \mathrm{a}$ \\
\hline 2 & $37.3 \pm 0.58 \mathrm{a}$ & $37.7 \pm 1.15 \mathrm{a}$ & $38.0 \pm 1.00 \mathrm{a}$ & $38.0 \pm 1.00 \mathrm{a}$ & $38.7 \pm 1.53 \mathrm{a}$ \\
\hline 3 & $38.0 \pm 1.00 \mathrm{bc}$ & $38.3 \pm 1.15 \mathrm{ab}$ & $38.7 \pm 0.58 \mathrm{ab}$ & $38.7 \pm 0.58 \mathrm{ab}$ & $39.7 \pm 0.58 \mathrm{a}$ \\
\hline \multirow[t]{2}{*}{ Mean \pm SD } & $37.3 \pm 0.80 \mathrm{ab}$ & $37.6 \pm 1.23 \mathrm{ab}$ & $37.8 \pm 0.75 \mathrm{ab}$ & $37.8 \pm 0.22 \mathrm{ab}$ & $38.6 \pm 0.54 \mathrm{a}$ \\
\hline & \multicolumn{5}{|c|}{ Flavour (40) } \\
\hline Fresh & $36.7 \pm 0.58 \mathrm{a}$ & $37.7 \pm 0.58 \mathrm{a}$ & $38.0 \pm 2.00 \mathrm{a}$ & $37.7 \pm 0.58 \mathrm{a}$ & $38.0 \pm 1.00 \mathrm{a}$ \\
\hline 1 & $37.0 \pm 1.00 \mathrm{ab}$ & $38.0 \pm 1.00 \mathrm{ab}$ & $38.3 \pm 0.58 \mathrm{a}$ & $38.0 \pm 1.00 \mathrm{ab}$ & $38.7 \pm 0.58 \mathrm{a}$ \\
\hline 2 & $37.7 \pm 0.58 \mathrm{ab}$ & $38.7 \pm 0.58 \mathrm{a}$ & $39.0 \pm 1.00 \mathrm{a}$ & $39.0 \pm 0.00 \mathrm{a}$ & $39.0 \pm 1.00 \mathrm{a}$ \\
\hline 3 & $38.7 \pm 0.58 \mathrm{a}$ & $39.0 \pm 1.00 \mathrm{a}$ & $39.3 \pm 0.58 \mathrm{a}$ & $39.0 \pm 1.00 \mathrm{a}$ & $36.3 \pm 5.51 \mathrm{a}$ \\
\hline \multirow[t]{2}{*}{ Mean \pm SD } & $37.5 \pm 0.47 \mathrm{ab}$ & $38.3 \pm 0.63 \mathrm{a}$ & $38.7 \pm 0.88 \mathrm{a}$ & $38.5 \pm 0.44 \mathrm{a}$ & $38.0 \pm 1.56 a b$ \\
\hline & \multicolumn{5}{|c|}{ Total (100) } \\
\hline Fresh & $90.7 \pm 1.53 \mathrm{bc}$ & $92.0 \pm 2.00 \mathrm{ab}$ & $93.3 \pm 3.21 \mathrm{ab}$ & $92.3 \pm 1.53 \mathrm{ab}$ & $94.7 \pm 1.15 \mathrm{a}$ \\
\hline 1 & $91.7 \pm 2.89 \mathrm{bc}$ & $93.3 \pm 3.51 \mathrm{abc}$ & $94.7 \pm 0.58 \mathrm{ab}$ & $93.3 \pm 1.15 \mathrm{abc}$ & $96.3 \pm 0.58 \mathrm{a}$ \\
\hline 2 & $93.0 \pm 1.73 \mathrm{bc}$ & $94.7 \pm 2.52 \mathrm{abc}$ & $96.7 \pm 2.08 \mathrm{a}$ & $96.3 \pm 1.53 \mathrm{ab}$ & $97.7 \pm 2.52 \mathrm{a}$ \\
\hline 3 & $95.7 \pm 2.08 \mathrm{ab}$ & $96.8 \pm 1.76 \mathrm{ab}$ & $97.7 \pm 0.76 \mathrm{a}$ & $97.3 \pm 0.76 \mathrm{ab}$ & $95.7 \pm 4.93 \mathrm{ab}$ \\
\hline Mean \pm SD & $92.7 \pm 1.78 \mathrm{bc}$ & $94.3 \pm 2.13 \mathrm{ab}$ & $95.6 \pm 1.55 \mathrm{a}$ & $94.9 \pm 0.54 \mathrm{ab}$ & $96.0 \pm 1.44 \mathrm{a}$ \\
\hline
\end{tabular}

Values are expressed as the mean standard deviation of three determinations.

a b c d e Letters indicate significant differences between processed cheese analogoues treatments.

Control: processed cheese without grape seeds.

GSP1: processed cheese containing $0.1 \%$ grape seeds powder.

GSP2: processed cheese containing $0.3 \%$ grape seeds powder. GSE1: processed cheese containing $0.1 \%$ grape seeds extract.

GSE2: processed cheese containing $0.3 \%$ grape seeds extract. 


\section{REFERENCES}

Abdrabba, S. and S. Hussein (2015). Chemical composition of pulp, seed and peel of red grape from Libya. GJSR, $3: 6-11$.

AOAC (2000). Official Methods of Analysis, Food Composition, additives and contamination $7^{\text {th }}$ Ed., Vol. 3 Public Association of Official Analytical Chemists, North Frederick Avenue, Gaitherdburg, Maryland, USA.

Arora, P., S.H. Ansari and I. Nazish (2010). Biofunctional aspects of grape seeds-A review. Int. J. Phytomedi., 2: 177-185.

Awad, R.A. and W.M. Salama (2010). Development of a novel processed cheese product containing fermented barley. Egypt. J. Dairy Sci., 38: 95-103.

Bachmann, H.P. (2001).Cheese analogues: A review. Int. Dairy J., 11: 505-515.

Bagchi, D., A. Garg, R. Krohn, M. Bagchi, M.X. Tran and S.J. Stohs (1997). Oxygen free radical scavenging abilities of vitamin $\mathrm{C}$ and $\mathrm{E}$ and a grape seed proanthocyanidin extract in vitro. Res. Commun. Mol. Pathol. Pharmacol., 95: 179- 186.

Benaouadj, F., A.H. Ziane-Zafour and M. Rebiha (2017). Effects of modified starch and fat on the rheological characteristics of newly formulated processed cheese: Use of experimental design method. J. Dispersion Sci. and Technol., 38 : 693-698.

Bourne, M.C. (1982). Food Texture and Viscosity. Academic press, New York (reprinted 1994).

Bourne, M.C. (2002). Food Texture and Viscosity: Concept and Measurement. $2^{\text {nd }}$ Ed. San Diego: Acad. Press, 415.

Chamber, M. and J. Daurelles (2000). Processed Cheese. In: Cheese making. From Science to Quality Assurance. EcK, A. and J.-C. Gillis (Eds), ( ${ }^{\text {rd }}$ Ed), Vererinaer, Denmark, 641657.

Chedea, V.S., C. Braicu, F. Chirilă, C. Ober and C. Socaciu (2011). Antibacterial action of an aqueous grape seed polyphenolic extract. Afr. J. Biotechnol., 10: 6276 - 6280.
Chemache, L. (2011). Quality of two cheese specialties manufactured and marketed in algeria. M.Sc. Thesis, Constantine Univ., Algeria, 1-73.

FAOSTAT (2013). Food and Agriculture Organization of the United Nations. Available from: http://faostat3. fao.org/ download/Q/QC/E. Accessed 2016 May 31.

Felix da Silva, D., P.T. Matumoto-Pintro, L. Bazinet, C. Couillard and M. Britten (2015). Effect of commercial grape extracts on the cheese-making properties of milk. J. Dairy Sci., 98: 1-11.

Gustaw, W. and S. Mleko (2007). The effect of polysaccharides and sodium chloride on physical properties of processed cheese analogues containing whey proteins. Milchwissenschaft, 62: 59-62.

Gwartney, E.A., D.K. Larick and E.A. Foegeding (2004). Sensory texture and mechanical properties of stranded and particulate whey protein emulsion gels. J. Food Sci., 69: S333-S339.

Houghtby, A.G., L.J. Maturin and K.E Koenig (1992). Microbiological count methods. In: Marshall RT (ed): Standard Methods for the Examination of Dairy Products, $16^{\text {th }}$ Ed., Washington, DC: Ame. Public Health Assoc., 213-246.

Jayaprakasha, G., T. Selviand and K. Sakariah (2003). Antibacterial and antioxidant activities of grape (Vitis vinifera) seed extracts. Food Res. Int., 36: 117-122.

Kim, S., S. Jeong, W. Park, K.C. Nam, D.U. Ahn and S. Lee (2006). Effect of heating conditions of grape seeds on the antioxidant activity of grape seed extracts. Food Chem., 97: 472-479.

Kosikowski, F.V. (1978). Cheese and Fermented Milk Foods. $2^{\text {nd }}$ Ed Cornell. Univ., Ithaca, New York.

Lee, S.C., J.H. Kim, S.M. Jeong, D.R. Kim, J.U. $\mathrm{Ha}$ and K.C. Nam (2003). Effect of farinfrared radiation on the antioxidant activity of rice hulls. J. Agri. and Food Chemi., 51 : 4400-4403. 
Maffei, F.R., M. Carini, G. Aldini, F. Berti, G. Rossoni, E. Bombardelli and P. Morazzoni (1996). Procyanidines from Vitis vinifera seeds protect rabbit heart from ischemia/ reperfusion injury: Antioxidant intervention and/or iron and copper sequestering ability. Planta Med., 62: 495-502.

Meyer, A. (1973). Processed Cheese Manufacture. Food Trade Press Ltd., London, UK.

Mildner-Szkudlarz, S. and J. Bajerska (2013). Protective effect of grape by-product fortified breads against cholesterol /cholic acid diet-induced hypercholesterolemia in rats. J. Sci. Food Agric., 93: 3271-3278.

Mohamed, A.G. and S.M. Shalaby (2016). Texture, chemical properties and sensory evaluation of a spreadable processed cheese analogues made with apricot pulp (Prunus armeniaca L.). Int. J. Dairy Sci., 11:61- 68.

Mohamed, A.G., A. F. Zayan and N.M. Shahein (2014). Physiochemical and sensory evaluation of yoghurt fortified with dietary fiber and phenolic compounds. Life Sci. J., 11: 816- 821 .

Nakamura, Y., S. Tsuji and Y. Tonogai (2003). Analysis of proanthocyanidins in grape seed extracts, health foods and grape seed oils. J. Health Sci., 49: 45-54.

Noronha, N., O.E.D. Riordan and M. O'Sullivan (2008). Influence of processing parameters on the texture and microstructure of imitation cheese. Eur. Food Res. Technol., 226: 385-393.
Park, S.H., T.S. Park and Y.S. Cha (2008). Grape seed extract (Vitis vinifera) partially reverses high fat diet-induced obesity in C57BL/6J mice. Nutr. Res. Prac., 2: 227-233.

Ohnishi, M., S. Hirose, M .Kawaguchi, S. Ito and Y. Fujino (1990). Chemical composition of lipids, especially triglycerol, in grape seeds. Agric. Biol. Chem., 54: 1035-1042.

Pereira, R.B., R.J. Bennett, Y. Hemar and O.H. Campanella (2001). Rheological and microstructural characteristics of model processed cheese analogues. J. Text. Stud., $32: 349-373$.

Sant'Anna, V., F.D.P. Christiano, L.D.F. Marczak, I.C. Tessaro and R.C.S. Thys (2014). The effect of the incorporation of grape marc powder in fettuccini pasta properties. LWT-Food Sci. Technol., 58 : 497-501.

Shin, Y.J., H.Y. Song, Y.B. Seo and K.B. Song (2012). Preparation of red algae film containing grapefruit seed extract and application for the packaging of cheese and bacon. Food Sci. Biotechnol., 21: 225-231.

Wichtl, M. (2004). Herbal Drugs and Phytopharmaceuticals $3^{\text {rd }}$ Ed. Boca Ratón, FL: CRC Press.

Zheng, Y., Z. Liu and B. Mo (2016). Texture profile analysis of sliced cheese in relation to chemical composition and storage temperature. J. Chem., 1-10. 
تأثير إضافة مسحوق بذور العنب ومستخلصاتها على التركيب الكيماوى والخصائص التصن

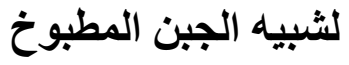

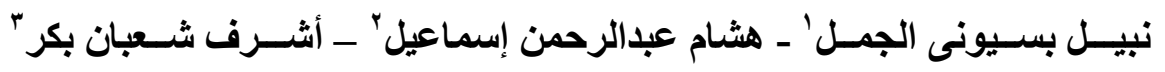

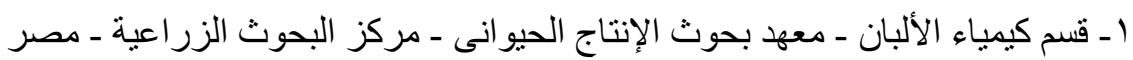

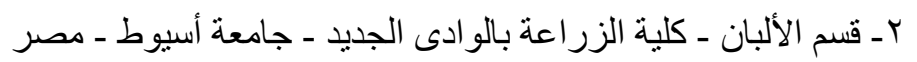

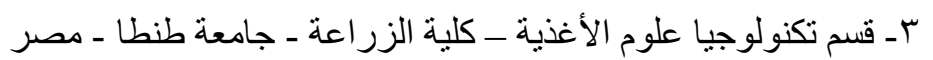

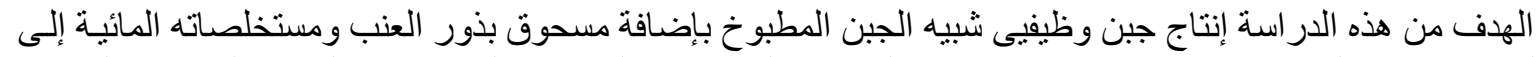

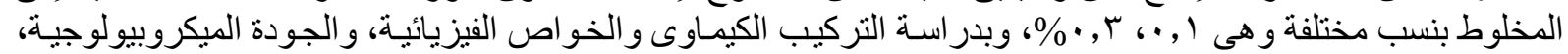

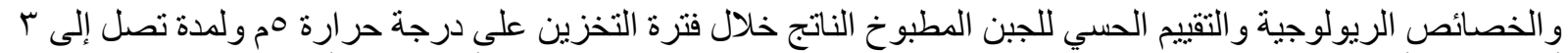

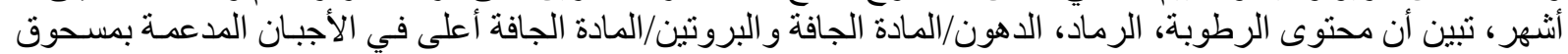

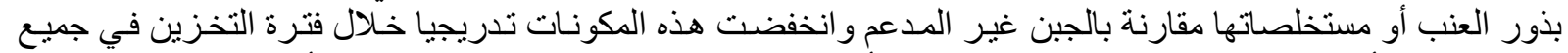

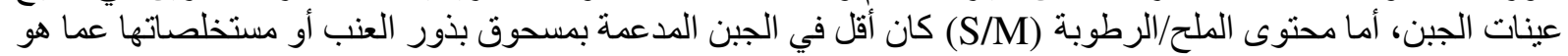

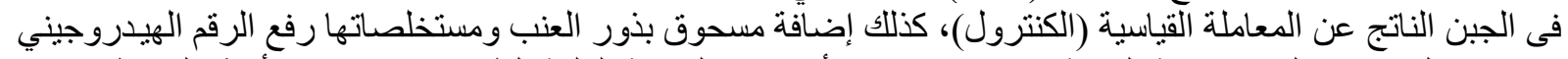

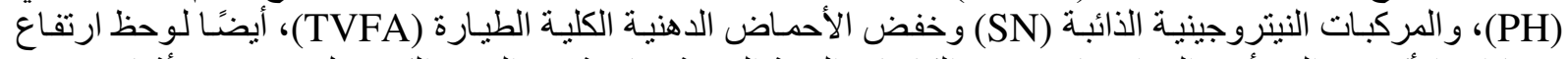

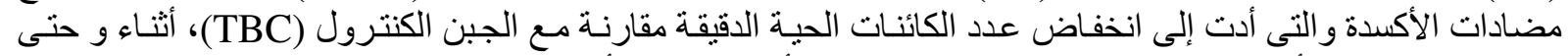

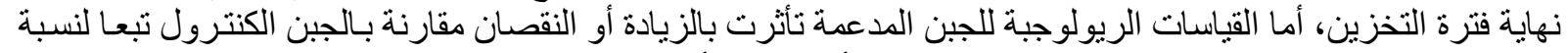

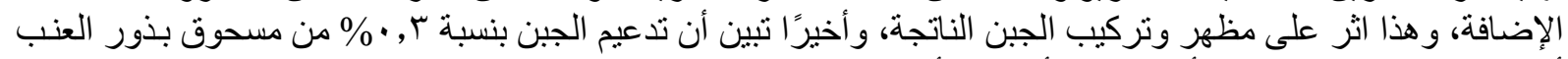

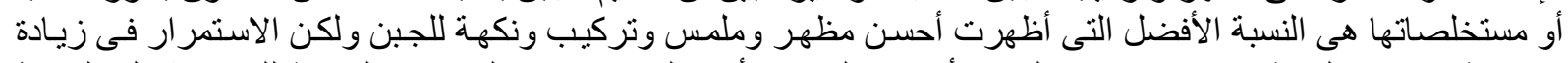

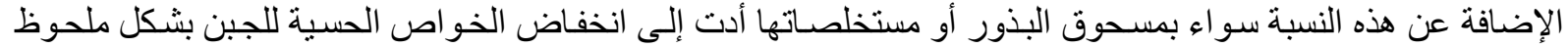
مقارنة مع الجبن الكنترول. 